\title{
Transitioning from military medics to registered nurses
}

\author{
This article was published in the following Dove Press journal: \\ Journal of Multidisciplinary Healthcare \\ 23 November 2015 \\ Number of times this article has been viewed
}

\author{
Mohamed D Keita' \\ Valerie J Diaz ${ }^{1,2}$ \\ Audrey P Miller \\ Maria Olenick' \\ Sharon R Simon' \\ 'Department of Undergraduate \\ Nursing, Nicole Wertheim College \\ of Nursing and Health Sciences, \\ Florida International University, \\ Miami, ${ }^{2}$ Operational Health Support \\ Unit Jacksonville, United States Navy \\ Nurse Corps, Jacksonville, FL, USA
}

Correspondence: Mohamed D Keita Nicole Wertheim College of Nursing and Health Sciences, Florida International University, I I 200 SW 8th Street, AHC3 - 232 Miami, FL 33199, USA

Tel +I 305348787 I

Fax +I 3053487764

Email mkeita@fiu.edu
Abstract: The nursing shortage in the USA is expected to reach 260,000 registered nurses (RNs) by 2025. The most profound shortages are expected in California and Florida, translating into 109,779 and 128,364 RN jobs, respectively. Despite a foreseen growth in nursing career opportunities nationwide, the supply of nurses will be insufficient to meet the corresponding demand. Capitalizing on prior education, experience, and skills of military clinical personnel to fill these jobs could significantly reduce the projected nursing shortage. Florida International University's Nicole Wertheim College of Nursing and Health Sciences is circumventing barriers to recruit, retain, and graduate transitioning veteran medics and corpsmen as Bachelor of Science in Nursing prepared RNs who reintegrate into the civilian workforce. The Veteran Bachelor of Science in Nursing (VBSN) program is in the form of a cooperative agreement between Florida International University and the US Health Resources and Services Administration. The VBSN program's main objective is to build upon the unique leadership skills, clinical education, and training of military medics and corpsmen to ensure successful completion of the Bachelor of Science in Nursing curriculum. VBSN students, as veterans themselves, have unique knowledge and exposure to the specific health issues and needs of the veteran population overall. They are poised and best prepared to effectively care for the US population, particularly the current 22 million US veterans and 1.6 million Florida veterans. Additionally, the VBSN program will alleviate the challenges, such as the lack of recognition of military skills, unemployment, the substandard income, and homelessness that many former service members face after separation from the military.

Keywords: veterans, corpsmen, Bachelor of Science in Nursing, Veteran Bachelor of Science in Nursing, registered nurse, nursing

\section{Introduction}

The USA is projected to face a shortage in the nursing profession. Factors such as the aging population, the aging nursing workforce, the lack of sufficient staffing, the high turnover observed in nursing, and the increase in access to health care due in part to the Patient Protection and Affordable Care Act, significantly contribute to the accelerating nursing shortage. ${ }^{1}$ The nursing shortage is expected to reach 260,000 registered nurses (RNs) by $2025 .{ }^{2}$ Research shows that by 2030 , the most profound shortages are expected in California and Florida, translating into 109,779 and 128,364 RN jobs, respectively. ${ }^{3}$ Despite the projected shortage, Florida is expected to see a $23 \%$ growth of its nursing workforce by $2022,{ }^{4}$ while the US Bureau of Labor Statistics projects a $19 \%$ growth of the nursing workforce nationwide from 2012 to $2022 .{ }^{4}$ Nonetheless, the supply of nurses will be insufficient to meet the corresponding demand. This translates into a 
demand for 530,000 additional RNs throughout the USA. ${ }^{1}$ Therefore, capitalizing on prior clinical education, experience, and skills of military personnel to fill these jobs could significantly help to reduce the projected nursing shortage nationwide, particularly in the State of Florida.

Indeed, Army and Air Force medics and Navy corpsmen possess exceptional clinical skills and are highly trained to render state-of-the-art care. Through education and training provided by the Joint Special Operations Medical Training Center, a complete range of US Special Operations Command medics have a comprehensive clinical foundation and a "solid understanding of the knowledge and skills required to provide treatment, regardless of the conditions." "The clinical training military personnel receive, and their accumulated experiences, allow them to perform a broad spectrum of services, such as primary care, emergency and urgent care, disaster relief, and public health. Training and education of military medics is based on curriculum similar to that used to train the civilian nursing workforce. Military medics and corpsmen endure a rigorous process of work evaluation that follows performance measurement based on competency. ${ }^{6}$

However, the civilian world is unaware of the quality of clinical training and education that medics and corpsmen receive, leaving a large portion of the potential health care workforce unexploited. At Fort Sam Houston, 12,500 men and women are trained every year to become combat medics, Navy corpsmen, and Air Force medical technicians. ${ }^{7}$ Additionally, more than 50,000 well-trained men and women were discharged from service between 2006 and $2010 .^{8}$ Despite the strong levels of clinical training and experience they possess, many military medics face barriers to transitioning into the civilian workforce, especially the nursing workforce. Nonetheless, they make quality candidates to fill nursing jobs, particularly after being discharged from the military with their health care experience and with additional nursing education. The State of Florida is home to 13 military bases and 1.6 million veterans. Wartime veterans make up $75 \%$ of Florida's 1.2 million total veteran population. California, Texas, and Florida are the states with the largest veteran populations, ${ }^{9}$ and many of these veterans are military medics.

The Iraq and Afghanistan Veterans of America, a veteran empowerment organization, purports that veterans including military trained medics that attempt to transition into the civilian health care workforce face several barriers. Veterans encounter difficulty translating their military education and training into applicable civilian attributes to secure gainful employment. ${ }^{10}$ State government legislation further compounds this issue by imposing enrollment in additional courses to obtain licensure in nursing. Also, male medics encounter a sex-specific barrier as they defy the perception that nursing is a woman's profession. ${ }^{6}$ Therefore, eliminating these barriers would significantly assist military medics to transition into the civilian nursing workforce, thereby reducing the projected nationwide nursing shortage in the years to come. Under the aegis of Florida International University (FIU), Nicole Wertheim College of Nursing and Health Sciences (NWCNHS) is circumventing barriers to recruit, retain, and graduate transitioning veteran medics and corpsmen as Bachelor of Science in Nursing (BSN)-prepared RNs who reintegrate into the civilian workforce.

\section{Florida International University and Nicole Wertheim College of Nursing and Health Sciences}

FIU is a public, federally designated Minority Serving Institution, and a Carnegie-Designated Doctoral Research Extensive University. Located in Miami, Florida, FIU is accredited by the Southern Association of Colleges and Schools. Its strategic plan emphasizes health, focusing on educating health professionals, and serving urban and international health needs. FIU's commitment to diversity, as exemplified in a city that is largely Hispanic and foreign-born, reflects a commitment to develop culturally and linguistically competent students from ethnically diverse backgrounds. ${ }^{11}$

The NWCNHS is an academic unit of FIU that hosts a culturally diverse faculty ( $49.4 \%$ minority) with expertise in research, clinical practice, and teaching that is able to address the varied learning styles and needs of a diverse student body. NWCNHS's mission emphasizes the preparation of "diverse health care professionals to serve as providers and leaders in the delivery of high quality, accessible, culturally competent, and compassionate care within a highly technological and global environment." ${ }^{12}$ Completing a BSN nursing curriculum provides graduates with the unique ability to focus care on not just the physical but the psychosocial, behavioral, and spiritual needs of patients and families, reflective of the framework of patient-centered culturally competent care upon which the NWCNHS is based. ${ }^{13}$ Recognizing the military experience as its own cultural entity, the Veteran Bachelor of Science in Nursing (VBSN) students' patient-care approach is augmented by this additional insight and thereby prepares students to address and impact disparities in health care locally and globally. FIU students are 61\% Hispanic, 15\% White, 13\% Black, 4\% Asian/Pacific Islander, and 7\% other minorities. ${ }^{11}$ FIU's students are similar representations of the 
diversity of the Miami-Dade County population comprising $85 \%$ racial and ethnic minorities, many of which (66\%) are foreign-born and reside in this underserved region. ${ }^{14}$

\section{The VBSN program}

The VBSN program is funded for 4 years in the form of a cooperative agreement between FIU and the US Health Resources and Services Administration. The purpose of the VBSN project is to develop, implement, and evaluate a Nurse Education, Practice, Quality, and Retention VBSN program at the NWCNHS. The VBSN program's main objective is to build upon the unique leadership skills, clinical education, and training of military medics and corpsmen to ensure successful completion of the BSN curriculum. The program will increase and diversify the nursing workforce by recruiting, retaining, and graduating $90+$ veteran medics and corpsmen over the course of 4 years. Students are recruited via word of mouth, advertisements in military publications, and use of social media. Of the three graduates the program has produced since its inception in the spring of 2014 , two $(67 \%)$ have obtained RN licensure and are gainfully employed in Florida medical facilities. ${ }^{15}$ Fifteen additional students will graduate in December 2015 and will be eligible to take the National Council Licensure Examination-RN (NCLEX-RN).

The current VBSN nursing student body boasts former licensed practical nurses, laboratory specialists, preventative medicine technicians, health care specialists, and emergency medicine technicians who have served in the Army (59\%), Navy (36\%), and the Air Force (9\%) as active duty personnel, reservists, and National Guardsmen. This diverse group has students who have relocated from California, New York, Texas, Georgia, Hawaii, and Germany. Nonetheless, its composition is a similar representation of the demographic of the South Florida region. ${ }^{16}$ Hispanic (41\%), African American $(36 \%)$, and White $(23 \%)$ are the racial groups represented. Male students account for $64 \%$ of the student body, which exceeds the national average for men in nursing. ${ }^{6}$ Through an accelerated curriculum, veteran students are provided with an opportunity to earn a BSN degree and be eligible to take the NCLEX-RN upon graduation. Reintegration into the nursing workforce allows veterans to rise above the poverty level, and avoid the predicaments of unemployment and homelessness that plague many veterans.

\section{The VBSN program of study}

Applicants to the VBSN program must meet distinct admission criteria for acceptance. In order to be considered for the program, applicants must be veterans of any branch of uniformed service, a drilling reservist, or a National Guardsmen. Applicants who were previous Army and Air Force medics or Navy corpsmen are preferred, however, the program also admits veterans who are civilian paramedics. In addition to the clinical experience requirements, applicants must have a minimum cumulative grade point average of 2.5 or higher in all lower college division coursework, complete the Test of Essential Academic Skills with $70 \%, 62 \%$ or higher in science, and earn a grade of " $\mathrm{C}$ " or better for all nursing prerequisite courses. Completion of an associate degree in any arts or science discipline is preferred, but is not a requirement.

The VBSN program of study is specifically targeted to the unique needs of veterans through use of a career ladder specifically structured to process, translate, and streamline a plethora of military credit earned by our veterans. Designed to build upon prior clinical education, experience, skills, and training, VBSN students receive credit for prior military didactic courses on a case-by-case basis. In addition, the VBSN students have the opportunity to demonstrate competencies in a Boot Camp course specifically designed for the VBSN program. Its purpose is to assess the baseline knowledge, skill, and ability of all students at the onset of the program. Each student possesses a unique military experience and perspective based on his or her branch of service. Through use of lecture, simulation, self-study modules, and adaptive testing, the fundamentals of nursing are reviewed while streamlining variability in students' experiences and competencies. Upon completion, students are awarded credit for Fundamentals in Nursing, Health Assessment, and for clinical hours associated with each. Thereafter, students complete nursing pathophysiology and nursing pharmacology and may begin the VBSN course curriculum. The VBSN students follow an accelerated, unique curriculum track that is rigorous and reflective of the spectrum of nursing care including health promotion, acute and long-term care, and end-of-life care. Upon graduation, students are prepared for licensure.

\section{Transitional resources}

The resources available to the VBSN students to assist in their transition from military life to student body are not only offered through the continuous access to faculty and staff, an academic advisor, and a success coach, but through the various resources available on FIU's campus. First, NWCNHS has the nationally renowned Simulation, Teaching, And Research Center (STAR Center), ${ }^{17,18}$ where students can 
practice their nursing skills and proficiency under the watchful and helpful eyes of their well-trained staff. The STAR Center maintains its national status as a research center and is supported by the National Council of State Boards of Nursing through their multisite simulation study. ${ }^{19}$ Additionally, the college has fully equipped testing and study rooms available to the students to prepare for class and/or exams.

On campus, the students have unlimited access to the Green Library for studying and research, as well as to designated staff to assist with the nursing and health sciences students and conducting research via online courses: the Centers for Academic Success; University Learning Center for tutorial services and the University Testing Center; FIU Online for courses that are either fully online or through fully online programs; the Reading and Writing Center; the Math Lab; and Counseling and Psychological Services for those students who need assistance with the management of stress and anxiety. For students with learning or medical disabilities, the Disability Resource Center is available to the students to aid in needed academic accommodations. ${ }^{20}$

Finally, the Veteran and Military Affairs Office is the hub of resources for the unique population for which we serve. The Veteran and Military Affairs Office aids the veteran student with accessing military benefits toward education like the GI Bill; financial resources for textbooks, technology, and child care services; and multiple other academic resources to guide them toward a successful career. ${ }^{20}$

\section{The VBSN program evaluation}

The VBSN program not only provides a gateway for veteran personnel to transition from military life to a professional career in nursing, but the program also offers a multitude of resources to aid in this transition. The program's objective is to elicit the strategies and resources that have been successful throughout the development and implementation of this program. Therefore, with the assistance of our Program Coordinator, we have collected data from the students on how to improve our program. All VBSN students receive an end-of-course evaluation, as well as an alumni exit survey. All data are collected and analyzed by the department of student services within the NWCNHS. According to the alumni exit survey administered through Qualtrics (Provo, UT, USA), there was $100 \%$ satisfaction with the VBSN nursing support personnel and availability of faculty throughout the program, as well as the course presentation, subject matter expertise, and the overall level of program difficulty. Additionally, students receive a monthly survey to garner which student resources have been utilized, which ones have been successful, and which ones have not. According to these data, resources such as the STAR Center, the Department of Veteran and Military Affairs, the NWCNHS computer labs, the Center for Academic Success, the Center for Excellence in Writing, and student services have been the most utilized and the most successful. The direct relation between these resources and class activities, as well as students' overall navigation through the program might explain this situation. However, the program encourages veteran students to take advantage of all the other resources available to them such as the Green Library and the University Technology Services. These valuable data will continue to guide the program and determine the students' success, as well as impart a respect toward the veterans for their contribution in sustaining this most needed and outstanding program.

\section{Health care and psychological issues}

VBSN students, as veterans themselves, have unique knowledge and exposure to the specific health and psychological issues of the veteran population overall. Health issues specific to veterans include but are not limited to tobacco use, drug use and abuse, general substance use disorder, rehabilitation care after injury, amputation, and traumatic brain injury. Psychological issues include posttraumatic stress disorder, depression and anxiety disorders, behavioral conditions (ie, aggression, fear, and hypervigilance), grief, loneliness, suicide, and military sexual trauma. In addition, veterans are plagued with social and legal issues such as homelessness, unemployment, social reintegration, divorce, and complex deployment issues (ie, financial difficulties).

VBSN students possess firsthand knowledge and exposure to military culture. Moreover, they are aware and more accustomed to military hierarchy, rank, war eras and specific health issues related to war eras, military traditions and code of conduct, values, communication styles, command, ceremony, loyalty, duty, and discipline. Therefore, VBSN students are uniquely poised and best prepared to most effectively care for the US population, particularly the current 22 million and 1.6 million US and Florida veterans, respectively. ${ }^{9,21}$ The need for the VBSN program is clear, given the projected shortages of nurses and low proportions of BSN-prepared nurses (41\%) for the entire country in $2011,{ }^{22}$ and $(26 \%$ ) for the State of Florida, with $\sim 18 \%$ coming from culturally diverse groups who can provide care for a population of nearly $44 \%$ minorities. ${ }^{16,23}$ 


\section{Benefits of the VBSN program Value-added of VBSN graduates to the nursing workforce}

Health care delivery is largely dependent on the $\mathrm{RN}$ workforce. The US Bureau of Labor Statistics ${ }^{24}$ projects that employment of RNs will grow $19 \%$ by 2022 compared with only $11 \%$ for occupations overall. Growth of the nursing workforce lags behind the increasing demand for BSN-prepared RNs, which is largely attributed to an aging population, increased focus on preventative health care, and an increase in access to care as a result of health care reform.

In 2014, 21 million US residents were veterans who previously served in the US Armed Forces. ${ }^{25}$ Veteran reintegration into civilian life can potentially be facilitated through building upon existing military education and training. Army and Air Force medics and Navy corpsmen possess the necessary education and training upon which to capitalize and further progress to become BSN graduates.

Nurses in the USA provide technologically advanced care in stressful and often chaotic environments. Medics and corpsmen are accustomed, and well suited to also provide care in similar settings. Navy corpsmen perform duties as assistants to physicians, dentists, and nurses in the prevention and treatment of disease and injury. Their scope of practice is diverse. Corpsmen can render emergency medical treatment on the battlefield, serve as surgical technicians in the operating room, fill prescriptions in the pharmacy, or independently perform patient care at remotely located duty stations where no other health care professionals exist. Similarly, Army and Air Force medics provide emergency medical care and evacuation in theater, and provide paraprofessional care in medical treatment facilities. Collectively, this group of clinically trained military personnel endure rigorous didactic and simulation training throughout their military careers. This suggests preparedness for progression through an accelerated BSN program in four semesters or less, as the American Council on Education recommends that prior military clinical experience and training be transferrable into college credits. ${ }^{26}$

Producing nurses from a pool of highly trained veterans meets the growing demand for RNs in Florida. FIU's VBSN program generates the supply to meet the demand for nurses statewide while simultaneously augmenting diversity. Approximately $85 \%$ of NWCNHS graduates are non-White, which is roughly a similar representation of the South Florida patient population. ${ }^{16}$ Moreover, the VBSN program has a $60 / 40$ male-to-female sex mix exceeding the
9.6\% national average of men in nursing as reported by the US Census Bureau. ${ }^{27}$ Furthermore, the program has a very diverse student body with multiple backgrounds, given that a diverse nursing workforce is most befitting to render culturally competent care to the increasingly diverse US patient population, thereby minimizing the profound health care disparity in the USA. ${ }^{28}$

The VBSN program has sparked a surge in veteran student enrollment in the NWCNHS and provided the impetus for infusing veteran-centered content into its nursing curriculum. Exposing veteran and civilian nursing students to the health care issues of all veterans will produce baccalaureate prepared nurses equipped to contribute to improving outcomes for this growing population, which stands at 22 million US residents. ${ }^{25}$ Furthermore, the NWCNHS provides faculty development regarding veteran culture and veteran characteristics to enhance teaching strategies that address the unique veterans student needs such as building upon leadership experience, and addressing the needs of veterans with physical or emotional disabilities that may impact learning. These veteran-centric efforts to enhance curriculum and teaching strategies are intended to recruit, retain, and graduate transitioning veterans as RNs and reintegrate them into the civilian nursing workforce. Additionally, the VBSN program will alleviate challenges, such as unemployment, substandard income, and homelessness that many former service members face after separation from the military.

\section{Reduced unemployment}

Many veterans, including military medics, face employment challenges in the civilian workforce after leaving the military. The Iraq and Afghanistan Veterans of America, in its 2009 report, attributed these challenges to the difficulty former service members have explaining and translating military skills, networking and negotiating comparable salaries, and separating themselves from the wrongful stigma of mental illness. ${ }^{10}$ These associated obstacles to securing decent employment in the civilian workforce have translated into a high rate of unemployment among veterans. In 2014, the US Bureau of Labor Statistics reported an unemployment rate of $5.3 \%$ among all veterans and $7.2 \%$ among post-9/11 veterans..$^{29}$ Yet, economic pundits identified Florida as a state more apt to hire veterans than any other. ${ }^{30}$ However, despite a large military presence, the unemployment rate among veterans in the State of Florida stands at 5.0\% $\%^{31}$ compared with a rate of $5.3 \%$ in the civilian world. ${ }^{32}$ Given the expected shortage in the nursing profession and the increasing demand 
for RN jobs, it is an opportune time for VBSN students graduating with a BSN to secure full-time employment as licensed RNs.

\section{Improved income}

Graduation from the VBSN program, and the opportunity for veterans to earn a BSN and become RNs, translates into a significant boost in salary for veterans and an improved lifestyle for this group and their families. The median salary for a new BSN-prepared nurse is $\sim$ US $\$ 57,759$ per year, ${ }^{33}$ while the average yearly earnings from wages and salary for veterans is \$US43,370. ${ }^{34}$ This boost in salary, and the associated lifestyle improvement, has the potential to lift many veterans out of financially overwhelming situations and poverty. According to a 2012 study, the poverty rate among recent veterans was estimated to be $5.1 \%{ }^{34}$

\section{Reduced homelessness}

Nearly 535,000 adults in the USA are homeless and of those, 49,933 have proudly served this country. ${ }^{35}$ Meanwhile, 1.4 million additional veterans are considered at risk because they face circumstances of poverty, substandard housing, overcrowding, and dismal living conditions. ${ }^{36}$ In 2013 , the National Coalition for Homeless Veterans estimated the number of homeless veterans to be around 5,500 in the State of Florida. In fact, the same organization reported that $44 \%$ of all homeless veterans in the country lived in Florida, California, and New York. ${ }^{37}$ A myriad of factors contribute to homelessness, such as the shortage of affordable housing, insufficient livable income, and unemployment. For many veterans, the complexities of homelessness are further compounded by posttraumatic stress disorder, substance abuse, and unemployability because military training is commonly unacknowledged in the civilian sector. ${ }^{38}$ The underlying premise of public and private coordinated efforts that support veterans is sustainable employment. Through the VBSN program, veteran medics and corpsmen are able to transition from military service to collegiate life and ultimately reintegrate into the workforce as registered professional nurses, thereby circumventing becoming a homeless statistic.

\section{Conclusion}

Army and Air Force medics, and Navy Corpsmen possess exceptional clinical skills and receive excellent training in care delivery, which could be utilized to add value to the nursing workforce and has the potential to substantially reduce the nursing shortage in the USA, particularly in the State of Florida. Unfortunately, the civilian sector is unaware of these skills and training. Service members including military clinical personnel face barriers in transitioning into the civilian workforce, which has been supported by the published literature. FIU's NWCNHS, through its flagship VBSN program, is eluding these barriers in recruiting, retaining, and graduating transitioning veteran medics and corpsmen as BSN-prepared RNs who reintegrate into the civilian workforce. Of the three VBSN graduates, two (67\%) have taken and passed NCLEX-RN licensure and secured full-time employment as RNs in Florida health facilities. Through this program, 15 additional students will graduate who will be eligible to sit for the NCLEX-RN in December 2015. Graduating BSN-prepared nurses addresses the profound nursing shortage, eliminates barriers that plagued transitioning veterans, and circumvents unemployment and homelessness. Current and future graduates of the NWCNHS are poised to contribute to improving outcomes for the growing veteran population and the South Florida community.

\section{Acknowledgments}

This project is supported by funds from the Division of Nursing and Public Health, Bureau of Health Workforce, Health Resources and Services Administration, Department of Health and Human Services Grants (UF1HP26491; UF1HP26980), Veteran Bachelor of Science in Nursing Program.

\section{Disclosure}

The authors report no conflicts of interest in this work.

\section{References}

1. AACN.NCHE.edu [web page on the Internet]. Nursing Shortage. Aliso Viejo, CA: AACN.NCHE.edu; nd (updated April 24, 2014). Available from: http://www.aacn.nche.edu/media-relations/fact-sheets/nursingshortage. Accessed April 15, 2015.

2. Buerhaus PI,Auerbach DI, Staiger DO. The recent surge in nurse employment: causes and implications. Health Aff. 2009;28(4):W657-W668.

3. Juraschek SP, Zhang XM, Ranganathan VK, Lin VW. United States registered nurse workforce report card and shortage forecast. Am J Med Qual. 2012;27(3):241-249.

4. American Nurses Association (ANA). Nursing Job Growth and Salaries by State. Silver Spring, MD: ANA; 2013. Available from: http://www. nursingworld.org/MainMenuCategories/ThePracticeofProfessional Nursing/workforce/Nursing-Job-Growth-and-Salaries-by-State.pdf. Accessed June 29, 2015.

5. US Army John F. Kennedy Special Warfare Center and School (USAJFKSWCS). Organization. Fort Bragg, NC: USAJFKSWCS; nd. Available from: http://www.soc.mil/SWCS/organization.html. Accessed April 15, 2015.

6. Halloran EJ. Men, medics, and nursing. Am J Nurs. 2009;109(6):11.

7. Lynch SL. Medics being all they can be find civilian job barriers. Bloomberg Business. September 11, 2012. Available from: http://www. bloomberg.com/news/articles/2012-09-11/medics-being-all-they-can-befind-civilian-job-barriers. Accessed April 15, 2015. 
8. Brock D, Bolon $\mathrm{S}$, Wick $\mathrm{K}$, et al. The military veteran to physician assistant pathway: building the primary care workforce. Acad Med. 2013;88(12):1890-1894.

9. US Department of Veterans Affairs. Veteran Population. Washington, DC: Department of Veterans Affairs; 2014. Available from: http://www. va.gov/vetdata/veteran_population.asp. Accessed June 25, 2015

10. Williamson V, Mulhall E. Careers After Combat: Employment and Education Challenges for Iraq and Afghanistan Veterans. New York, NY: Iraq and Afghanistan Veterans of America (IAVA); 2009. Available from http://www.dillonconsult.com/wp-content/uploads/2013/03/CareersAfter-Combat-Employment-and-Education-Challenges-for-Iraq-andAfghganistan-Veterans-IAVA-Jan.-2009.pdf. Accessed May 14, 2015.

11. FIU.edu [web page on the Internet]. About Us. Miami, FL: FIU.edu; nd. Available from: http://www.fiu.edu/about-us/index.html. Accessed June 26, 2015.

12. CNHS.FIU.edu [web page on the internet]. Mission, Vision, and Strategic Plan. Miami, FL: CNHS.FIU.edu; nd. Available from: http://cnhs.fiu.edu/ about-us/mission-and-vision/index.html. Accessed October 7, 2015.

13. CNHS.FIU.edu [web page on the internet]. About Us: Letter from the Dean. Miami, FL: CNHS.fiu.edu; nd. Available from: http://cnhs.fiu. edu/about-us/letter-from-the-dean/index.html. Accessed September 29, 2015.

14. Census.gov [web page on the internet]. States and County Quickfacts: Miami-Dade County. Washington, DC: Census.gov; 2014 [updated May 29, 2015]. Available from: http:/quickfacts.census.gov/qfd/ states/12/12086.html. Accessed June 29, 2015.

15. Boyle R. Battle-tested veterans earn FIU nursing degrees. FIU News. November 7, 2014. Available from: https://news.fiu.edu/2014/11/ medic-to-nurse-program/82617. Accessed September 30, 2015.

16. Census.gov [web page on the internet]. State and County Quickfacts: Florida. Washington, DC: Census.org; nd [updated May 28, 2015]. Available from: http:/quickfacts.census.gov/qfd/states/12000.html. Accessed June 26, 2015.

17. FIU Nursing and Health Sciences. Community Report. Miami, FL: Florida International University; 2013. Available from: http://cnhs.fiu. edu/_assets/documents/media-center/newsletters/2013_spring_CNHS_ Newsletter_FINAL.pdf. Accessed September 30, 2015.

18. Cheapnursedegrees.com [web page on the internet]. Nursing Degree Programs in Florida. Cheapnursedegree.com; nd. Available from: http:// www.cheapnursedegrees.com/in/florida-a-n/. Accessed September 30, 2015.

19. NCSBN.org [web page on the Internet]. Simulation Study. Chicago, IL: NCSBN.org; nd. Available from: https://www.ncsbn.org/685.htm. Accessed October 7, 2015

20. CNHS.FIU.edu [web page on the Internet]. Student Resources. Miami, FL: CNHS.FIU.edu; nd. Available from: http://cnhs.fiu.edu/studentresources/index.html. Accessed June 26, 2015.

21. US Department of Veterans Affairs. Veteran Population Projections: FY2010 to FY2040. Office of the Actuary. Washington, DC: Department of Veterans Affairs; 2011. Available from: http:/www.va.gov/vetdata/ docs/QuickFacts/population_quickfacts.pdf. Accessed May 28, 2015.

22. Health Resources and Services Administration(HRSA). The US Nursing Workforce: Trends in Supply and Education. Bureau of Health Professions. National Center for Health Workforce Analysis. Rockville, MD: HRSA; 2013. Available from: http://bhpr.hrsa.gov/healthworkforce/ reports/nursingworkforce/nursingworkforcefullreport.pdf. Accessed June 25, 2015.

23. Miami Dade College (MDC). Proposal for a Bachelor of Science in Nursing: Executive Summary. Miami, FL: MDC; 2006. Available from http://www.mdc.edu/asa/oap/documents/BSN_Proposal_Final_ Redline_12-15-2006.doc. Accessed June 24, 2015.
24. US Bureau of Labor Statistics (BLS). Employment Projections: 2012-2022. Washington, DC: BLS; 2013. Available from: http://www. bls.gov/news.release/pdf/ecopro.pdf. Accessed April 16, 2015.

25. US Department of Veterans Affairs. Veterans Population Quickfacts. Washington, DC: National Center for Veterans Analysis and Statistics; 2015. Available from http://www.va.gov/vetdata/docs/QuickFacts/ Population_quickfacts.pdf. Accessed June 25, 2015.

26. Luckwaldt A. How to Become a Registered Nurse in the Military. About. com. nd. Available from: http://militarycareers.about.com/od/CareerProfiles/p/How-To-Become-A-Registered-Nurse-In-The-Military.htm. Accessed October 7, 2015.

27. US Census Bureau. Men in Nursing Occupations: American Community Survey Highlight Report. Washington, DC: Census Bureau; 2013. Available from: https://www.census.gov/people/io/files/ Men_in_Nursing_Occupations.pdf. Accessed June 26, 2015.

28. American Association of Colleges of Nursing (AACN). Cultural Competency in Baccalaureate Nursing Education. Aliso Viejo, CA: AACN; 2008. Available from: http://www.aacn.nche.edu/leading-initiatives/ education-resources/competency.pdf. Accessed June 26, 2015.

29. BLS.gov [web page on the Internet]. Employment Situation of Veterans Summary. Washington, DC: BLS.gov; 2014 [updated March 18, 2015]. Available from: http://www.bls.gov/news.release/vet.nr0.htm. Accessed May 14, 2015.

30. Feloni R, Kiersz A. How veteran unemployment compares to overall unemployment in every state. Business Insider, July 15, 2014. Available from: http://www.businessinsider.com/us-veteran-unemployment-ineach-state-2014-7. Accessed June 26, 2015.

31. Joint Economic Committee (JEC). Veterans' Unemployment Rates by State: 2014 Annual Averages. The US Congress Democratic Staff. Washington, DC: JEC; 2014. Available from: http://www. jec.senate.gov/public/_cache/files/1deb8b29-90b5-45d7-bccdb6915b2dc919/2014-veterans-sbs-data-table---updated---5.20.15.pdf. Accessed June 25, 2015

32. BLS.gov [web page on the Internet]. Local Area Unemployment Statistics, Florida. Washington, DC: BLS.gov; 2015 [extracted on September 30, 2015]. Available from: http://data.bls.gov/timeseries/ LASST120000000000003. Accessed September 30, 2015.

33. Learn.org [web page on the Internet]. What is the Average Salary for a Nursing Graduate with a BSN. Mountain View, CA: Learn.org; nd. Available from: http://learn.org/articles/What_is_the_Average_Salary_ for_a_Nursing_Graduate_with_a_BSN.html. Accessed July 1, 2015.

34. Wihbey J. Veterans, jobs, wages and employment issues: research round-up. Journalist's Resource. March 25, 2015. Available from: http://journalistsresource.org/studies/government/security-military/ veterans-wages-unemployment-issues-research-roundup\#. Accessed July 1, 2015.

35. National Alliance to End Homelessness (NAEH). The State of Homelessness in America 2015. Washington, DC: NAEH; 2015. Available from: http://b.3cdn.net/naeh/458837a0513453bec1_56m6zdnl3.pdf. Accessed June 26, 2015.

36. National Coalition for Homeless Veterans (NCHV). FAQ About Homeless Veterans. Washington, DC: NCHV; nd. Available from: http:// nchv.org/index.php/news/media/background_and_statistics/.Accessed June 26, 2015.

37. National Coalition for Homeless Veterans (NCHV). Location of Homeless Veterans, Knowledge, Corporate Connection. Washington, DC: NCHV; nd. Available from: http://www.nchv.org/index.php/connect/ story/location. Accessed June 26, 2015.

38. Johnson BS, Boudiab LD, Freundl M, Anthony M, Gmerek GB, Carter J. Enhancing veteran-centered care: a guide for nurses in non-VA settings. Am J Nurs. 2013;113(7):24-39. 


\section{Publish your work in this journal}

The Journal of Multidisciplinary Healthcare is an international, peerreviewed open-access journal that aims to represent and publish research in healthcare areas delivered by practitioners of different disciplines. This includes studies and reviews conducted by multidisciplinary teams as well as research which evaluates the results or conduct of such teams or

healthcare processes in general. The journal covers a wide range of areas and welcomes submissions from practitioners at all levels, from all over the world. The manuscript management system is completely online and includes a very quick and fair peer-review system. Visit http://www.dovepress.com/testimonials.php to read real quotes from published authors.

Submit your manuscript here: http://www.dovepress.com/journal-of-multidisciplinary-healthcare-journal 